\title{
Alpha-1 antitrypsin is a potential biomarker for hepatitis $B$
}

Xu-fei Tan ${ }^{1,2}$, Shan-shan $\mathrm{Wu}^{1}$, Shu-ping $\mathrm{Li}^{1}$, Zhi Chen ${ }^{1}$ and Feng Chen ${ }^{1 *}$

\begin{abstract}
Background: Function exertion of specific proteins are key factors in disease progression, thus the systematical identification of those specific proteins is a prerequisite to understand various diseases. Though many proteins have been verified to impact on hepatitis, no systematical protein screening has been documented to hepatitis $B$ virus (HBV) induced hepatitis, hindering the comprehensive understanding to this severe disease.

Aim: To identify the major proteins in the progression of HBV infection from mild stage to severe stage.

Methods: We performed an integrated strategy by combining two-dimensional electrophoresis (2-DE), peptide mass fingerprinting (PMF) analysis, and tissue microarray techniques to screen the functional proteins and detect the localization of those proteins.

Results: Interestingly, MS/MS identification revealed the expression level of alpha-1 antitrypsin (AAT) was significantly elevated in serum samples from patients with severe chronic hepatitis. Immunoblotting with a specific AAT antibody confirmed that AAT is highly expressed in serum samples from patients with hepatic carcinoma and severe chronic hepatitis. Furthermore, we observed that AAT is with highest expression in normal tissue and cells, but lowest in hepatic carcinoma and severe chronic hepatitis tissues and cells, suggesting the specific secretion of AAT from tissues and cells to serum.
\end{abstract}

Conclusion: These results suggest the possibility of AAT as a potential biomarker for hepatitis B in diagnosis.

\section{Introduction}

Alpha-1 antitrypsin (AAT) is the most prominent protease inhibitor in human serum. More than 70 genetic variants of AAT have been described. It was documented that ATT deficiency associates with various types of liver diseases, such as neonatal hepatitis [1], cirrhosis and hepatoma [2].

Hepatitis B continues to be a worldwide clinical problem with approximately 300 million people chronically infected. Chronic infection is associated with significant morbidity and mortality as a result of long-term sequelae including inflammatory liver disease, cirrhosis, and hepatocellular carcinoma [3]. It's well known that different functions of specific proteins play crucial roles in hepatitis B virus (HBV) induced hepatitis, thus comprehensive identification of those specific proteins may

\footnotetext{
* Correspondence: zjuchenfeng@gmail.com

${ }^{1}$ State Key Laboratory of Infectious Disease Diagnosis and Treatment, First Affiliated Hospital, College of Medicine, Zhejiang University, Zhejiang, 310003 China

Full list of author information is available at the end of the article
}

greatly advance the disease diagnosis and biomarker search. To this end, many technologies were developed to identify disease associated proteins and biomarkers in diagnosis. Among them, proteomic analysis is a powerful tool to advance the diagnosis, treatment, and prevention of human diseases $[4,5]$. Two-dimensional electrophoresis (2-DE) is also widely used to identify biomarkers for diagnosis and therapeutic strategies. Steel et al. [6] constituted a proteomic approach for the discovery of early detection markers of hepatocellular carcinoma and Qing-Yu He et al. [7] used SELDI-ProteinChip combined with 2-DE to identify biomarkers in the serum samples of hepatitis B and hepatic carcinoma. However, these technology-dependent studies only displayed the expression of protein in the serum, but protein origin information was not provided, hindering the deep understanding to the investigated diseases.

In this study, we first applied 2-DE to screen specific proteins in the serum samples from mild and severe hepatitis B patients and alpha-1 antitrypsin (AAT) with high expression was identified. Using tissue microarray
C Biomed Central

(C) 2011 Tan et al; licensee BioMed Central Ltd. This is an Open Access article distributed under the terms of the Creative Commons Attribution License (http://creativecommons.org/licenses/by/2.0), which permits unrestricted use, distribution, and reproduction in any medium, provided the original work is properly cited. 
technique with few reagents [8], we confirmed the AAT identification by 2-DE. Furthermore, SELDI-TOF MC PMF was used to expand the protein information. Our studies thus provided useful information of the origin of AAT, which will be valuable for further explorations, especially specific amino acids.

\section{Materials and methods Patient Materials}

Approved by the local ethics committee, 31 chronic hepatitis $B$ patients (13 mild and 18 severe), 10 convalescent acute hepatitis B (AHB), 18 HBV-related Hepatocellular Carcinoma (HCC) patients and 12 healthy blood donors (normal controls) were enrolled in this study. The standards for diagnoses have been described previously [9]. All patients were HBsAg positive, and patients with hepatitis $C$, hepatitis $D$, human immunodeficiency virus type $1[\mathrm{HIV}-1]$ positive and HIV-2 negative as well as with other chronic liver damages were excluded. Venous blood was collected and centrifuged at $2000 \mu \mathrm{g}$ for $10 \mathrm{~min}$. The supernatant were obtained and stored at $-80^{\circ} \mathrm{C}$.

\section{2-DE protein separation}

In order to identify the target proteins in the progress of HBV patients from mild to severe, one-milliliter of serum was collected from each patient of these two groups. The serum from mild and severe group were separately mixed. The serum albumin and IgG were removed using an albumin and IgG removal kit (GE healthcare, London, UK). The protein concentrations were determined by a Bradford assay. 2-DE was performed with IPGphor IEF (Amersham Biosciences, Uppsala, Sweden) and Ettan Dalt six electrophoresis units with the protocol suggested by the manufacturer. Isoelectric focusing (IEF) was performed using $240 \mathrm{~mm}$ IPG strips with IPGphor system. Two hundred micrograms of protein sample was diluted with rehydration solution (8 M urea, 2\% (w/v) CHAPS, 0.5\% (v/v) IPG buffer $\mathrm{pH} 4-7,0.002 \%(\mathrm{w} / \mathrm{v})$ bromophenol blue) to 450 $\mu \mathrm{l}$ and then loaded on the strip holder. Six gels were separated at once, three per group. The IPG gels were rehydrated for $12 \mathrm{hrs}$ under $30 \mathrm{~V}$ at $20 \mathrm{~W}$. IEF was performed with the following parameters: $500 \mathrm{~V}$ for $1 \mathrm{~h}$, $1000 \mathrm{~V}$ for $1 \mathrm{hr}, 8000 \mathrm{~V}$ for $8 \mathrm{hrs}$ and $20 \mathrm{~min}$. After IEF, the strips were equilibrated for $15 \mathrm{~min}$ in SDS equilibration buffer (6M urea, 2\% (w/v) SDS, $50 \mathrm{mM}$ Tris$\mathrm{HCl} \mathrm{pH} \mathrm{8.8,} \mathrm{30 \%} \mathrm{(v/v)} \mathrm{glycerol,} 0.002 \%(\mathrm{w} / \mathrm{v})$ bromophenol blue) containing $100 \mathrm{mM}$ DTT and then in SDS equilibration buffer containing $250 \mathrm{mM}$ idoacetamide. After equilibration, the strips were loaded onto a vertical $12.5 \%(\mathrm{w} / \mathrm{v})$ SDS-PAGE gels and sealed with $0.5 \%(\mathrm{w} / \mathrm{v})$ agarose. The vertical electrophoresis was performed at $10 \mathrm{~W}$ with a condition of $5 \mathrm{~W} /$ gel for $30 \mathrm{~min}$ followed by $15 \mathrm{~W} /$ gel until the bromophenol blue dye reached the bottom of the gel.

\section{Silver staining and imaging of 2DE gels}

The gels were fixed with $40 \%(\mathrm{v} / \mathrm{v})$ ethanol and $10 \%$ $(\mathrm{v} / \mathrm{v})$ acetic acid over night, and then incubated in the sensitizing solution $(30 \%(\mathrm{v} / \mathrm{v})$ ethanol, $0.2 \%(\mathrm{w} / \mathrm{v})$ sodium thiosulphate and $6.8 \%(\mathrm{w} / \mathrm{v})$ sodium acetate) for $30 \mathrm{~min}$. After washing three times with milli-Q water for $15 \mathrm{~min}$ each, the gels were stained with $0.25 \%(\mathrm{w} / \mathrm{v})$ silver nitrate solution for $20 \mathrm{~min}$. Development was performed in $2.5 \%(\mathrm{w} / \mathrm{v})$ sodium carbonate with $0.04 \%(\mathrm{v} / \mathrm{v})$ formaldehyde for $5 \mathrm{~min}$. Stop solution $(1.46 \%(\mathrm{w} / \mathrm{v})$ EDTA) was used to terminate the reaction.

\section{In-gel trypsin digestion of proteins}

The selected protein spots from all gels were excised and placed in Eppendorf tubes and digested as previously described [10]. After washing twice in milli-Q water, the gels were destained with a 1:1 mixture of $30 \mathrm{mM}$ potassium ferricyanide and $100 \mathrm{mM}$ sodium thiosulfate. The gels were then washed twice in milli-Q water, dehydrated with ACN and dried in a SpeedVac for $20 \mathrm{~min}$. The gels were digested over night with $10 \mu \mathrm{l}$ of $20 \mathrm{ng} / \mu \mathrm{l}$ sequencing grade trypsin at $37^{\circ} \mathrm{C}$. The peptide fragments were extracted with $30 \mu \mathrm{l}$ solution containing $50 \%(\mathrm{v} / \mathrm{v})$ ACN and $5 \%(\mathrm{v} / \mathrm{v})$ TFA. The solutions containing peptide fragments were dried in a lyophilizer and reconstituted by adding $10 \mu \mathrm{l}$ of $0.1 \%(\mathrm{v} / \mathrm{v})$ formic acid.

\section{MALDI-TOF-MS analysis of tryptic peptide}

MS/MS analysis was performed using a Bruker-Daltonics AutoFlex TOF-TOF LIFT Mass Spectrometer (Bruker, Germany) operated in the delayed extraction and linear mode. The tryptic digest mixture was mixed with HCCA matrix. The MALDI spectra averaged over 50 laser shots. All mass spectra were calibrated externally by using a standard peptide mixture (HCCA). Internal calibration was performed using automatic digestion peaks of trypsin.

\section{Database searching and identification of proteins}

Peptide mass fingerprints obtained by the MALDI-TOF MS were used to search NCBInr using Mascot software. The parameters used for the search were as follows: (1) peptide mass ranged from 1,000 to 3,000 U; (2) modifications were allowed for carbamidomethyl and oxidation; (3) one missed cleavage site was allowed; (4) mass accuracy was $\pm 1 \mathrm{U}$, and (5) restriction was placed on the species of Mus. The criteria for positive identification of proteins were set as follows: (1) the MS match consisted of a minimum of four peptides; (2) the matched peptides covered at least $20 \%$ of the whole protein sequence, and (3) $100 \mathrm{ppm}$ or better mass accuracy. 


\section{Preparation of AAT polyclonal antibody}

An anti-human AAT rabbit polyclonal antibody was generated by EPITOMICS (EPITOMICS, USA), recognizing the amino acid residues 301 to 314 . The antibody generation procedure was described as previously [11].

\section{Western Blotting}

Serum proteins (10 ug) from each patient of mild, severe CHB patients, acute hepatitis B patients, HCC patients, and healthy control groups were separated on $12 \%$ SDSPAGE gels, and then transferred onto PVDF membranes. After incubating with blocking solution (TBS-T containing 5\% non-fat milk) under room temperature for $2 \mathrm{hrs}$, the membranes were probed with anti-human AAT rabbit polyclonal antibody at $4^{\circ} \mathrm{C}$ overnight. After washing four times of $10 \mathrm{~min}$ each with TBS-T, antirabbit (horse-radish peroxidase) HRP secondary antibody was added for $1 \mathrm{hr}$ at room temperature, and the antigen-antibody interaction was detected by ECL detection kit and exposed to X-ray film.

\section{Immunohistochemical analysis of tissue microarrays}

A tissue microarray block with 24 tissue sample cores (each $1.5 \mathrm{~mm}$ in diameter) was purchased from Cybrdi (CC03-11-002, United States). The 24 tissue samples were formalin-fixed, paraffin-embedded liver samples consisting of six cases of multiple types of cancer with matched normal controls. Slides from the tissue microarray block were deparaffinized. For antigen retrieval, the sections were immersed in citrate buffer and processed in a scientific microwave oven at $95^{\circ} \mathrm{C}$ for 10 min. After pretreatment with biotin blocking, rabbit anti-human AAT rabbit polyclonal antibody was applied at a dilution of 1:1000 and incubated at $4^{\circ} \mathrm{C}$ overnight. Biotinylated goat anti-rabbit IgG (1:100 dilution; Dako, Gene Tech) was used as a secondary antibody. Negative controls were created by omitting the primary antibody.

Assessment of AAT was based on the percentage of positive stained cells on a 3 -point scale $(0$, absence of staining; $1+$, moderate staining; $2+$, strong staining).

\section{Cell line culture, extraction, and western blotting}

Chang cells, HepG2, Huh7, 7402, 7721 cells were cultured in DMEM medium supplemented with $10 \%(\mathrm{v} / \mathrm{v})$ fetal bovine serum (FBS) and antibiotics. The cells were maintained in an incubator at $37^{\circ} \mathrm{C}$ with $\mathrm{CO}_{2}$ in humidified atmosphere. The cells at the exponential growth phase were harvested with trypsinization. Then cells were lysed with lysis buffer (30 mM Tris, pH7 .5, $150 \mathrm{mM}$ sodium chloride, $1 \mathrm{mM}$ phenylmethylsulfonyl fluoride, 1 $\mathrm{mM}$ sodium orthovanadate, $1 \%$ Nonidet P- $40,10 \%$ glycerol) [12] for 15 mins at $4^{\circ} \mathrm{C}$, vortexed and centrifuged at $13000 \mathrm{rpm}$ at $4^{\circ} \mathrm{C}$ for $30 \mathrm{~min}$. The supernatants were mixed in Laemmli loading buffer, boiled for $10 \mathrm{~min}$, and then subjected to SDS-PAGE gels.

\section{Results}

The screening of specific proteins associated with severe hepatitis $B$

To screen the proteins contributing to the progress of chronic hepatitis B (CHB), 2DE separation of serum protein was performed. 2-DE separation was performed three times for each sample of one group to minimize gel-to-gel variation (Figure 1A/B). Figure 1A showed the representative gel images from patients with mild $\mathrm{CHB}$, while Figure 1B showed the image from patients with severe CHB. Spot size was compared between two gel images with ImageMaster. With the same quantity of total serum protein loading, it was clearly observed that the size of most spots in Figure 1B is smaller than those in Figure 1A except one area indicated in Figure 1C. Due to the unexpected observation, we next focused on those proteins in the following studies.

\section{Protein identification}

The spot highlighted in Figure $1 \mathrm{C}$ was excised and subjected to trypsin digestion followed by MALDI-TOF identification. Database searching suggested it was alpha-1 antitrypsin (AAT) (Table 1, Figure 2).

\section{Western blot analysis of serum protein}

To further confirm the protein identified by MALDITOF, western blotting was performed with the generated ATT antibody. In order to reveal the relationship between hepatitis B and AAT, more samples from different patients including healthy controls, acute hepatitis, and chronic hepatitis (including mild, severe, and hepatic carcinoma) were included. Among the serum samples from those groups, six samples in each group were randomly selected and subjected to the immunoblotting with anti-human AAT rabbit polyclonal antibody. With equal loading amount, highest ATT expression levels were in carcinama and severe chronic hepatitis B samples, but relatively lower in serum samples from normal and mild $\mathrm{CHB}$ patients (Figure 3), which is consitent with the results of 2-DE gel seperation.

\section{AAT immunostaining on tissue microarrays}

Immunostaining for AAT was performed on the consecutive tissue microarray sliders. A total of 24 samples were analyzed, and 13 of those were divided into four types as cholangiocarcinoma, hepatocellular carcinoma, transparent hepatocellular carcinoma, and moderate differentiated metastatic adenocarcinoma. Eleven of those samples were noncancerous liver samples including chronic hepatitis and normal liver samples. Non-cancerous livers with 


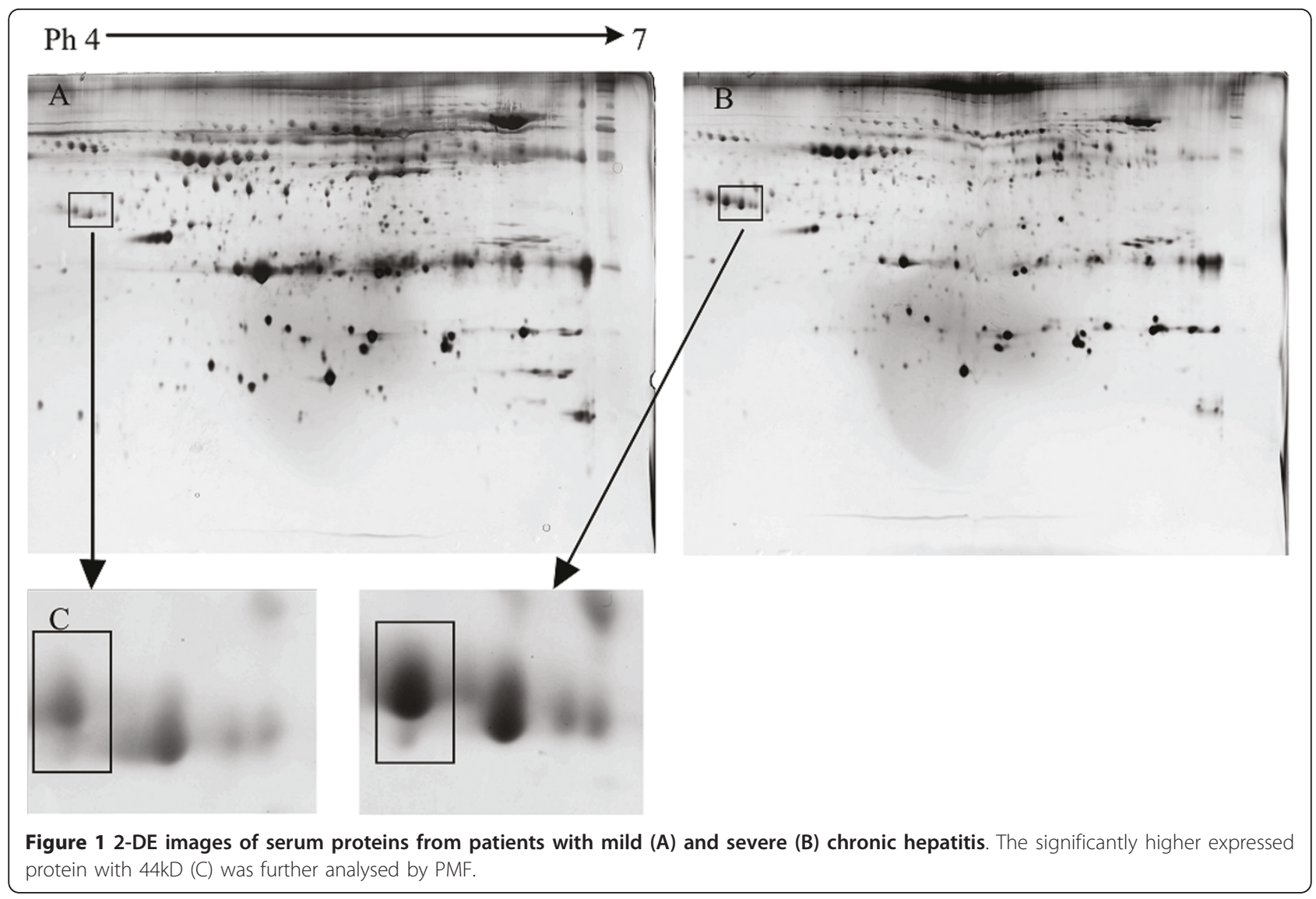

chronic hepatitis and normal liver samples exhibit significant cytoplasmic staining of AAT compared with the HCC's (Figure 4). Even in the one slide of HCCs, the noncancerous area was found to be significantly expressed with AAT compared with the carcinoma areas.

\section{Western blotting analysis of protein from cell lines}

To further confirm the results from tissue microarrays, we next carried out western blotting in different cell lines including hepatic carcinoma cell line HepG2, 2215, HepG2, Huh7, BEL-7402 [13], SMMC-7721 [14] and normal hepatic cell line Chang [15]. With equal protein loading, proteins from all cell lines were subjected to the immunoblotting with anti-human AAT rabbit polyclonal antibody. As shown in Figure 5, the AAT signal was only detected in normal hepatic Chang cells, but not in other cell lines. These results are consistent with the data from tissue microarrays.

Table 1 MALDI-TOF identification and database search for protein identification

\begin{tabular}{cccc}
\hline Protein & $\begin{array}{c}\text { Peptides } \\
\text { matched }\end{array}$ & $\begin{array}{c}\text { Protein } \\
\text { score }\end{array}$ & $\begin{array}{c}\text { Experimental } \\
\text { (MW) }\end{array}$ \\
\hline $\begin{array}{c}\text { alpha-1 } \\
\text { antitrypsin }\end{array}$ & 6 & 67 & $44179 \mathrm{Da}$ \\
\hline
\end{tabular}

\section{Discussion}

Identification of biomarkers with proteomic technology has become an important tool in biomedical research. The development of proteomics, especially two-dimensional electrophoresis associated with MS/MS, provides tremendous assistance to screen the biomarkers in various diseases. Many studies focus on biomarker identification for HBV infection [16,17], liver fibrosis, or cirrhosis that may result in HCC [18]. However, the methodology used in these studies only detect proteins in the serum, but not the tissues that secret or express these proteins.

J. Kenonen et al. [19] firstly introduced microarray technology in biomedical research, making hundreds of samples to be detected simultaneously by either immunohistochemistry or in situ hybridization on a single tissue slice $[20,21]$. As a result, in our study we combined 2-DE with high-throughput tissue microarray technology to study proteins that may be involved in the progression of mild hepatitis B infection to severe or even HCC in the patients. According to the result of SELDI-TOF MS PMS, we identified the highly expressed AAT in serum samples from patients with hepatic carcinoma severe hepatitis $\mathrm{B}$.

To study the association between AAT and hepatitis B and HBV-related HCC, we prepared polyclonal antibody 


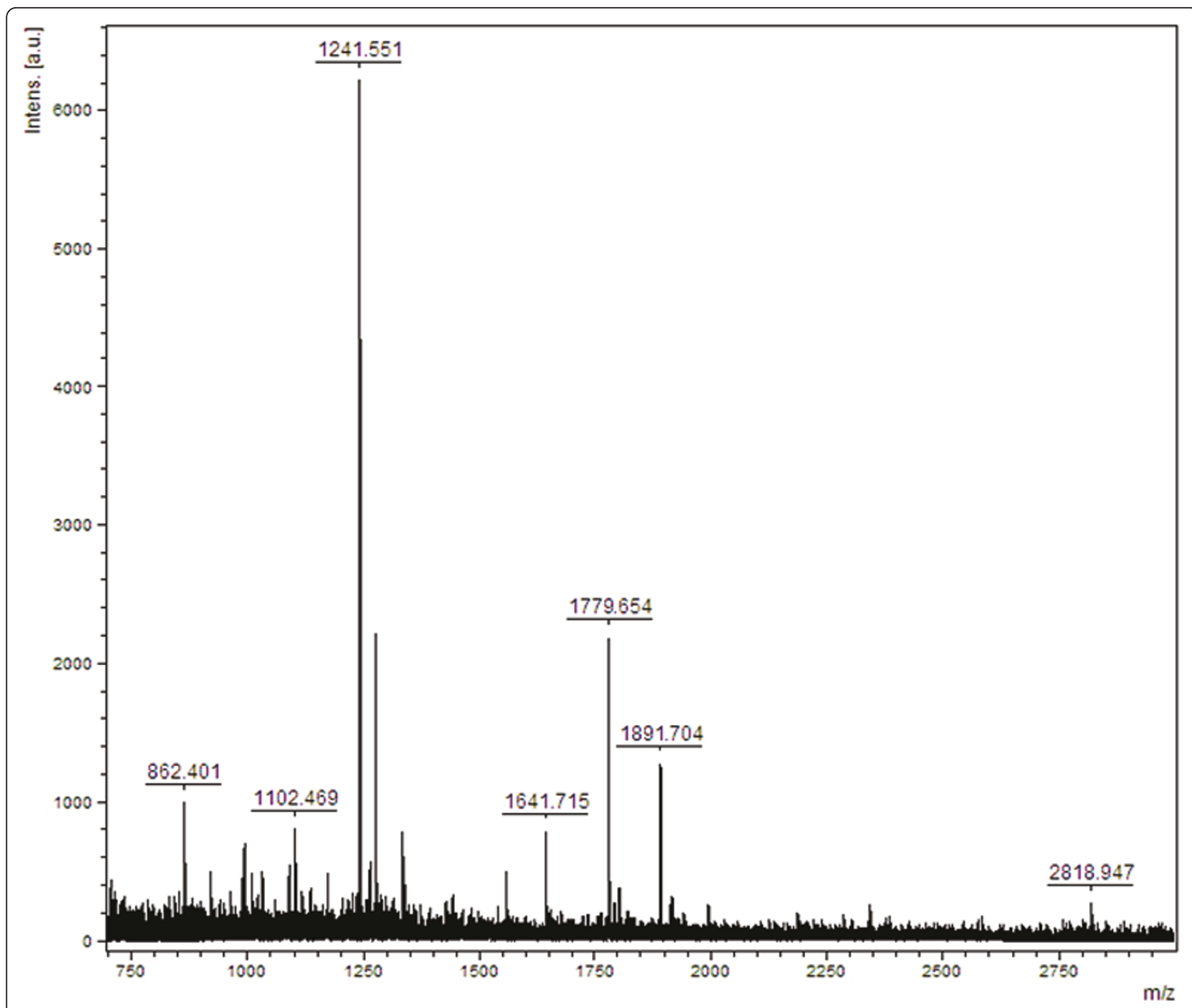

Figure 2 MALDI-TOF MS spectrum of alpha-1 antitrypsin. The major peaks are well matches to the protein sequence with probability based mowse score is 67. [Protein score is $-10^{*} \log (\mathrm{P})$, where $\mathrm{P}$ is the probability that the observed match is a random event. Protein scores greater than 65 are significant $(p<0.05)$.].

against AAT and performed western blotting exam. Results showed the gradual increase of serum AAT level from normal to hepatitis B patients and then to the HCC group. We further performed immunohistochemical analysis on hepatic tissue microarray slice. To verify

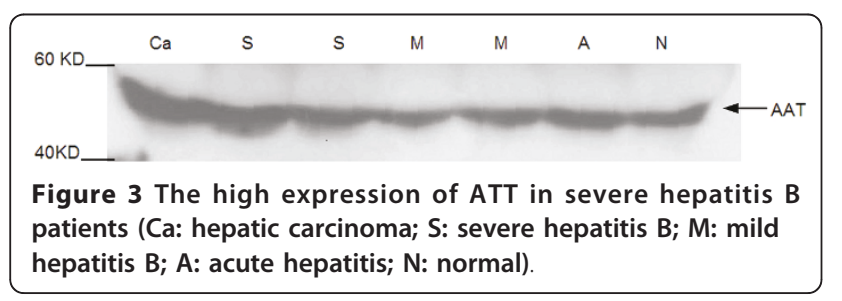

the result of tissue chips, we further examined the AAT expression in different cell lines including HepG2 Huh7 7402 and 7721 hepatoma cell lines (Chang cells were set as normal control) by western blotting and the results showed AAT was only expressed in Chang cells but not other hepatitis cells or hepatic hepatoma cells. The discrepancy of ATT expression in serum and tissue/cell samples suggested the different mechanism by which ATT is expressed/secreted.

Blood plasma is with exceptional proteome in many respects, containing other tissue proteomes as subsets. As a widely used research subject, serum has its intrinsic advantages such as the convenience for preparation and rich aspects linking with various diseases. However, 


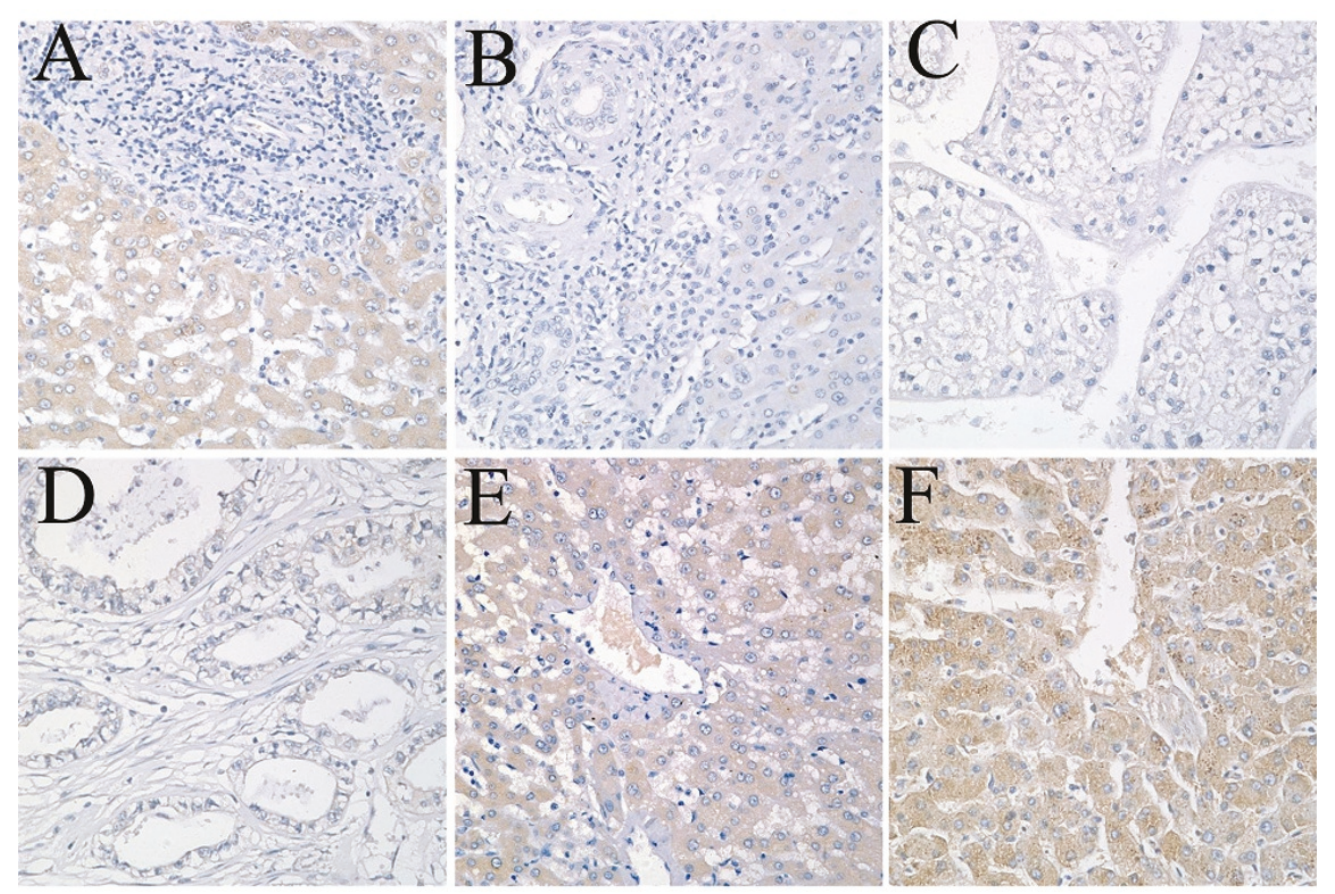

Figure 4 Immunostaining for AAT on the tissue mircroarrays. (A) Cholangiocarcinoma sample. (B) HCC sample. (C) Transparent HCC sample. (D) Moderate differentiated metastatic adenocarcinoma sample. (E) CHB sample. (F) Cancer adjacent normal liver tissue (set as positive control). (Original magnification: $A$ to $G, \times 40$ ).

there are many disadvantages such as proteins in serum from various tissue proteomes, which makes serum not able to be used to determine the origins of disease associated proteins [22]. In our experiments, though the conclusion of AAT levels in serum, tissue and cell lines were not consistent, it is not difficult to understand that the high ATT level in serum may be secreted from hepatic carcinoma or hepatitis cells by certain inflammatory molecules or signal pathway activation, causing ATT levels in hepatic carcinoma or hepatitis cells invisible. On the other hand, the high level of AAT in serum may be derived from normal liver cells and represent self-protective responses of the liver cells as observed in other studies [23].

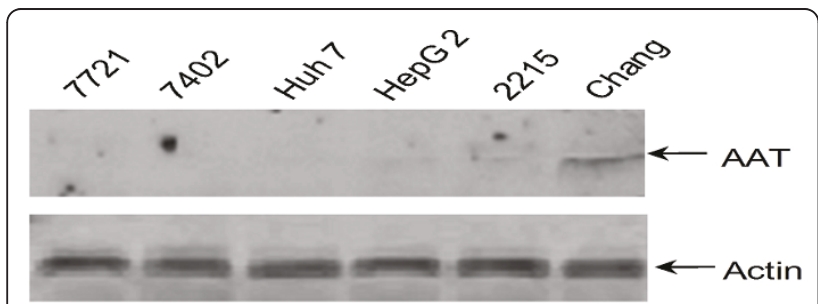

Figure 5 AAT expression in different cell lines. Six types of cells indicated were lysed and equal amount of proteins were subjected to SDS-PAGE. The fractionized proteins were blotted with anti-AAT and anti-Actin antibodies.

\section{List of abbreviations}

AAT: alpha-1 antitrypsin; AHB: acute hepatitis B; CHB: chronic hepatitis B; HBV: hepatitis B virus; HCC: Hepatocellular Carcinoma; HRP: horse-radish peroxidase; IEF: Isoelectric focusing; PMF: peptide mass fingerprinting; 2-DE: two-dimensional electrophoresis

\section{Acknowledgements}

Funding: The work was supported by the State S \& T Projects (11th Five Year) (2008ZX10002-007)

\section{Author details}

${ }^{1}$ State Key Laboratory of Infectious Disease Diagnosis and Treatment, First Affiliated Hospital, College of Medicine, Zhejiang University, Zhejiang, 310003 China. ${ }^{2}$ Department of Pulmonary Diseases and Biomedical Research Center, Sir Run Run Shaw Hospital, College of Medicine, Zhejiang University, Zhejiang, 310003 China.

\section{Authors' contributions}

CF and CZ proposed the study. TXF wrote the first draft and analyzed the data. All authors contributed to the design and interpretation of the study and to further drafts. CF is the guarantor. All authors have read and approved the final manuscript.

\section{Competing interests}

No benefits in any form have been received or will be received from a commercial party related directly or indirectly to the subject of this article.

Received: 30 March 2011 Accepted: 5 June 2011 Published: 5 June 2011

\section{References}

1. Sharp HL, Bridges RA, Krivit W, Freier EF: Cirrhosis associated with alpha-1antitrypsin deficiency: a previously unrecognized inherited disorder. J Lab Clin Med 1969, 73:934-9.

2. Eriksson $\mathrm{S}$, Carlson J, Velez R: Risk of cirrhosis and primary liver cancer in alpha 1-antitrypsin deficiency. N Engl J Med 1986, 314:736-9. 
3. Chisari FV, Ferrari C: Hepatitis B virus immunopathogenesis. Annu Rev Immunol 1995, 13:29-60.

4. Borman S: Proteomics: Taking over where genomics leaves off. Chem Eng News 2000, 78(31):31-37.

5. Hunt DF: Personal commentary on proteomics. J Proteome Res 2002, 1:15-9.

6. Steel LF, Mattu TS, Mehta A, Hebestreit H, Dwek R, Evans AA, London WT, Block T: A proteomic approach for the discovery of early detection markers of hepatocellular carcinoma. Dis Markers 2001, 17:179-89.

7. He QY, Zhu R, Lei T, Ng MY, Luk JM, Sham P, Lau GK, Chiu JF: Toward the proteomic identification of biomarkers for the prediction of HBV related hepatocellular carcinoma. J Cell Biochem 2008, 103:740-52.

8. Kallioniemi OP, Wagner U, Kononen J, Sauter G: Tissue microarray technology for high-throughput molecular profiling of cancer. Hum Mol Genet 2001, 10:657-62.

9. Xu XW, Lu MH, Tan DM: Association between tumour necrosis factor gene polymorphisms and the clinical types of patients with chronic hepatitis B virus infection. Clin Microbiol Infect 2005, 11:52-6.

10. Wilm M, Shevchenko A, Houthaeve T, Breit S, Schweigerer L, Fotsis T, Mann M: Femtomole sequencing of proteins from polyacrylamide gels by nano-electrospray mass spectrometry. Nature 1996, 379:466-9.

11. Lin $C T$, Chen LH, Chan TS: A comparative study of polyclonal and monoclonal antibodies for immunocytochemical localization of cytosolic aspartate aminotransferase in rat liver. J Histochem Cytochem 1983, 31:920-6.

12. Pan $\mathrm{H}$, Hong F, Radaeva S, Gao B: Hydrodynamic gene delivery of interleukin-22 protects the mouse liver from concanavalin A-, carbon tetrachloride-, and Fas ligand-induced injury via activation of STAT3. Cell Mol Immunol 2004, 1:43-9.

13. Shi $P$, Huang $Z$, Tan $X$, Chen G: Proteomic detection of changes in protein expression induced by cordycepin in human hepatocellular carcinoma BEL-7402 cells. Methods Find Exp Clin Pharmacol 2008, 30:347-53.

14. Feng $Y$, Tian ZM, Wan MX, Zheng ZB: Protein profile of human hepatocarcinoma cell line SMMC-7721: identification and functional analysis. World J Gastroenterol 2007, 13:2608-14.

15. Tan F, Lu L, Cai Y, Wang J, Xie Y, Wang L, Gong Y, Xu BE, Wu J, Luo Y, Qiang B, Yuan J, Sun X, Peng X: Proteomic analysis of ubiquitinated proteins in normal hepatocyte cell line Chang liver cells. Proteomics 2008, 8:2885-96

16. He QY, Chiu JF: Proteomics in biomarker discovery and drug development. J Cell Biochem 2003, 89:868-86.

17. Comunale MA, Mattu TS, Lowman MA, Evans AA, London WT, Semmes OJ, Ward M, Drake R, Romano PR, Steel LF, Block TM, Mehta A: Comparative proteomic analysis of de- $\mathrm{N}$-glycosylated serum from hepatitis $\mathrm{B}$ carriers reveals polypeptides that correlate with disease status. Proteomics 2004 4:826-38.

18. Poon TC, Hui AY, Chan HL, Ang IL, Chow SM, Wong N, Sung JJ: Prediction of liver fibrosis and cirrhosis in chronic hepatitis B infection by serum proteomic fingerprinting: a pilot study. Clin Chem 2005, 51:328-35.

19. Kononen J, Bubendorf L, Kallioniemi A, Barlund M, Schraml P, Leighton S, Torhorst J, Mihatsch MJ, Sauter G, Kallioniemi OP: Tissue microarrays for high-throughput molecular profiling of tumor specimens. Nat Med 1998, 4:844-7.

20. Rimm DL, Camp RL, Charette LA, Costa J, Olsen DA, Reiss M: Tissue microarray: a new technology for amplification of tissue resources. Cancer f 2001, 7:24-31.

21. Frantz GD, Pham TQ, Peale FV Jr, Hillan KJ: Detection of novel gene expression in paraffin-embedded tissues by isotopic in situ hybridization in tissue microarrays. J Pathol 2001, 195:87-96.

22. Anderson NL, Anderson NG: The human plasma proteome: history, character, and diagnostic prospects. Mol Cell Proteomics 2002, 1:845-67.

23. Yu J, Hui AY, Chu ES, Cheng AS, Go MY, Chan HL, Leung WK, Cheung KF, Ching AK, Chui YL, Chan KK, Sung JJ: Expression of a cyclo-oxygenase-2 transgene in murine liver causes hepatitis. Gut 56:991-9.

doi:10.1186/1743-422X-8-274

Cite this article as: Tan et al: Alpha- 1 antitrypsin is a potential biomarker for hepatitis B. Virology Journal 2011 8:274.

\section{Submit your next manuscript to BioMed Central and take full advantage of:}

- Convenient online submission

- Thorough peer review

- No space constraints or color figure charges

- Immediate publication on acceptance

- Inclusion in PubMed, CAS, Scopus and Google Scholar

- Research which is freely available for redistribution 